\title{
PENGEMBANGAN MEDIA PEMBELAJARAN BERBENTUK PERMAINAN EDUKASI AKUNTANSI CARI KATA (ACAK) MENGGUNAKAN ADOBE FLASH CS5
}

\section{DEVELOPMENT PERMAINAN ACAK AS ACCOUNTING EDUCATION LEARNING MEDIA}

\author{
Oleh: \\ Intan Nur Saidah \\ Pendidikan Akuntansi Universitas Negeri Yogyakarta \\ intansaidah25@gmail.com \\ Mahendra Adhi Nugroho
}

Staf Pengajar Jurusan P. Akuntansi Universitas Negeri Yogyakarta

\begin{abstract}
Abstrak
Penelitian ini bertujuan untuk 1) mengembangkan media pembelajaran berbentuk Permainan Edukasi Akuntansi Cari Kata (ACAK), dan 2) mengetahui kelayakan Permainan Edukasi Akuntansi Cari Kata (ACAK) sebagai media pembelajaran. Penelitian ini adalah penelitian dan pengembangan (Research and Development). Subjek dalam penelitian ini adalah peserta didik SMK YPE Sawunggalih kelas XI jurusan Akuntansi, ahli materi, ahli media dan praktisi pembelajaran Akuntansi Keuangan SMK dan objek penelitian adalah pengembangan media pembelajaran berbentuk Permainan Edukasi Akuntansi Cari Kata (ACAK). Analisis data yang digunakan untuk mengetahui kelayakan adalah deskriptif kuantitatif dengan persentase. Pengembangan media pembelajaran Permainan Edukasi Akuntansi Cari Kata (ACAK) dengan Analysis, Design, Development, Implementation dan Evaluation (ADDIE). Penilaian 1) uji coba perorangan mendapatkan Baik dan Sangat Layak (83.49\%), 2) uji coba kelompok kecil Baik dan Sangat Layak (85.23\%), 3) uji coba lapangan Baik dan Sangat Layak (81.14\%), 4) ahli materi Sangat Baik dan Sangat Layak (93.91\%), 5) ahli materi adalah Baik dan Sangat Layak $(91.25 \%)$, 6) praktisi pembelajaran Akuntansi SMK Baik dan Sangat Layak $(82.85 \%)$. Berdasarkan hasil penilaian dari keenam tahapan maka media pembelajaran Permainan Edukasi Akuntansi Cari Kata (ACAK) dinyatakan Sangat Layak (86.31\%) untuk digunakan sebagai media pembelajaran Akuntansi Keuangan pada kompetensi dasar Aset Tetap kelas XI Akuntansi SMK YPE Sawunggalih.
\end{abstract}

Kata Kunci: Media Pembelajaran, Permainan Edukasi, Akuntansi Cari Kata (ACAK)

\begin{abstract}
This research aimed to 1) developing Permainan Edukasi ACAK as accounting education learning media and 2) determine the feasibility of Permainan Edukasi ACAK as accounting education learning media. This research is a type of research and development $(R \& D)$. Subjects in this research are students in $11^{\text {th }}$ grade of accounting at SMK YPE Sawunggalih, subject matter expert, media expert and financial accounting teacher of SMK and the object is the development of Permainan Edukasi ACAK as accounting education learning media. Analysis the data used to determine eligibility is quantitative descriptive percentages. Development of learning media in Permainan Edukasi ACAK with analysis, design, development, implementation and evaluation (ADDIE). The results showed that the level of Permainan Edukasi ACAK as accounting education learning media based on: 1) one to one trying out is included in the category of good and very worthy (83.49\%), 2) small group try out is included in the category of good and very worthy $(87.74 \%)$, 3) field try out is included in the category of good and very worthy $(81.14 \%), 4)$ subject matter expert is included in the category of very good and very worthy (93.91\%), 5) media expert is included in the category of very good and very worthy $(91.25 \%)$, 6) financial accounting teacher of SMK is included in the category of
\end{abstract}


very good and very worthy (82.85\%). Based on the results the six stage assessment, stated very worhty (86.31\%) to be used as accounting education learning media for fixed assets basic competence in finance accounting in $11^{\text {th }}$ grade of accounting at SMK YPE Sawunggalih.

Keyword: Learning media, Permainan Edukasi, ACAK

\section{PENDAHULUAN}

Pendidikan saat ini sudah menjadi salah satu investasi jangka panjang yang sangat menguntungkan. Tujuan pendidikan yang tertuang dalam Pembukaan UUD 1945 yaitu mencerdaskan kehidupan bangsa. Oleh karena itu setiap unsur pendidikan harus diperhatikan agar dapat tercapai. Keberhasilan proses pembelajaran menjadi faktor penting dalam mewujudkan tujuan pendidikan tersebut. Pembelajaran menuntut keaktifan kedua belah pihak yang samasama menjadi subjek pembelajaran. Dengan demikian pembelajaran adalah proses penyampaian pesan dari sumber pesan melalui saluran atau media tertentu kepada penerima pesan. Salah satu strategi pembelajaran adalah strategi penyampaian pembelajaran. Strategi pembelajaran ini erat kaitannya dengan penggunaan media saat proses pembelajaran.

Media dalam dunia pendidikan diartikan segala sesuatu yang dapat digunakan untuk menyalurkan pesan (bahan pembelajaran), sehingga dapat merangsang perhatian, minat, pikiran dan perasaan peserta didik dalam kegiatan belajar untuk mencapai tujuan belajar. Media pembelajaran ada berbagai macam, berikut adalah klasifikasi media pembelajaran menurut taksonomi Leshin, dkk. (Arsyad, 2008: 81-101) yaitu media berbasis manusia, media berbasis cetakan, media berbasis visual, media berbasis audio visual dan media berbasis komputer. Media berbasis komputer (computer assisted instruction) adalah aplikasi komputer sebagai bagian integral dalam sistem pembelajaran terhadap aktivitas belajar mengajar. Software pengembang media pembelajaran berbasis komputer salah satunya adalah Adobe Flash CS5. Adobe Flash CS5 merupakan software yang mampu menghasilkan presentasi, permainan, film serta web yang interaktif.
Peneliti melakukan observasi awal yang dilakukan pada masa Kuliah Kerja Nyata dan Praktik Pengalaman Lapangan (KKN PPL) di SMK Y PE Sawunggalih Kutoarjo pada bulan Juli sampai September 2014 dan observasi lanjutan pada 25 Januari 2015. Berdasarkan observasi yang dilaksanakan pada kelas XI jurusan Akuntansi masih ditemui hambatan dalam proses pembelajaran yakni ketidakefektifan penyampaian materi pembelajaran ditandai dengan kurangnya perhatian peserta didik ketika pendidik menyampaikan materi pembelajaran. Temuan berikutnya adalah kurangnya pemanfaatan media pembelajaran oleh pendidik. Keterbatasan pemanfaatan media pembelajaran ini yang membuat peserta didik merasa bosan dan mengabaikan materi pembelajaran yang diajarkan. Media pembelajaran yang digunakan adalah buku teks akuntansi dan LKS (Lembar Kerja Siswa). Media pembelajaran tersebut masih konvensional. Peserta didik menginginkan media pembelajaran interaktif dan tidak membosankan.

Mata pelajaran Akuntansi dianggap sulit oleh peserta didik. Kendala ini sudah menjadi penghalang besar dalam penyampaian materi akuntansi. Aset Tetap sebagai salah satu kompetensi inti mata pelajaran akuntansi, dalam pembelajarannya membutuhkan ketelitian dan kecermatan dalam praktiknya. Untuk pembelajaran akuntansi kompetensi inti Aset Tetap, pendidik membutuhkan media pembelajaran yang menarik untuk tetap memfokuskan perhatian peserta didik pada materi pembelajaran. Masalah utama yang dihadapi ketika materi Aset Tetap adalah waktu pembelajaran di sekolah yang relatif singkat dikarenakan adanya praktik industri. Oleh karena itu, pendidik membutuhkan pengembangan media yang baru dan efektif. 


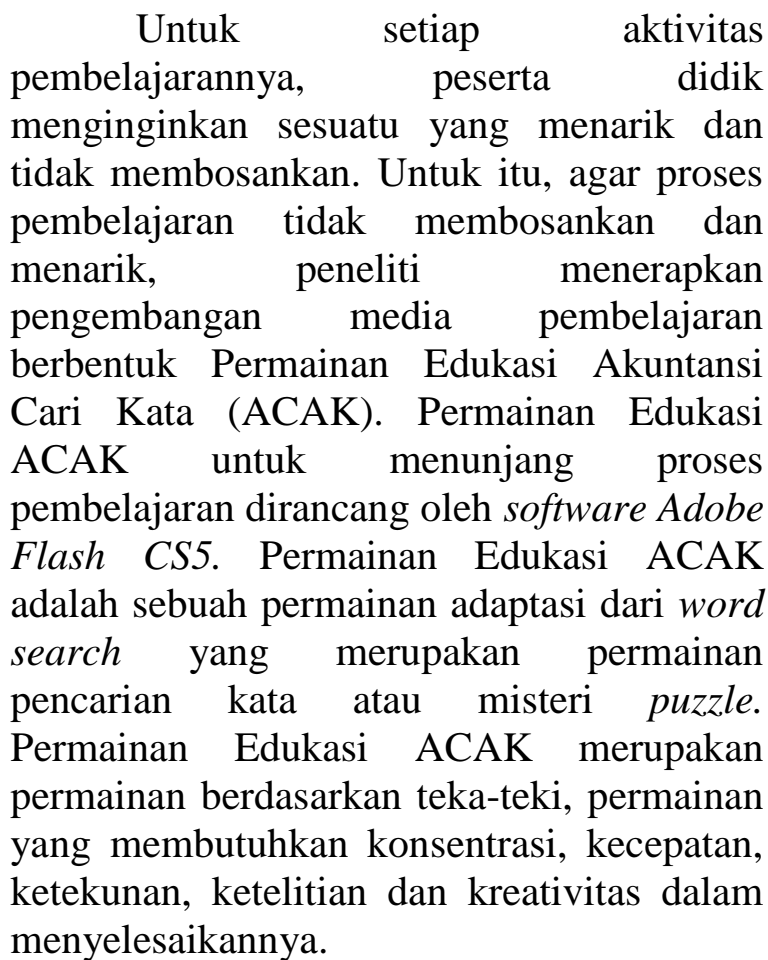

Berdasarkan permasalahan di atas, maka perlu dilakukan penelitian untuk pengembanagan media berjudul "Pengembangan Media Pembelajaran Berbentuk Permainan Edukasi Akuntansi Cari Kata (ACAK) Dengan Menggunakan Software Adobe Flash CS5 untuk Pembelajaran Akuntansi Keuangan Kompetensi Dasar Aset Tetap di Kelas XI SMK YPE Sawunggalih Kutoarjo Tahun Ajaran 2014/2015".

\section{METODE PENELITIAN Jenis Penelitian}

Penelitian ini merupakan penelitian riset dan pengembangan atau Research and Development (R\&D). Produk yang akan dikembangkan dalam penelitian ini adalah Permainan Edukasi Akuntansi Cari Kata dengan menggunakan Software Adobe Flash CS5 untuk Pembelajaran Akuntansi Keuangan Kompetensi Dasar Aset Tetap. Dalam penelitian ini digunakan model penelitian yang dikembangkan oleh Dick dan Carey yaitu analysis, design, development, implementation and evaluation (ADDIE).

\section{Waktu dan Tempat Penelitian}

Peneliti melakukan penelitian di SMK YPE Sawunggalih Kutoarjo yang beralamat di Jalan Semawung Daleman, Desa Semawung Daleman, Kecamatan Kutoarjo, Kabupaten Purworejo, Jawa Tengah, 54213. Penelitian ini dilaksanakan secara bertahap dalam kurun waktu bulan Januari 2015 - Mei 2015 yang meliputi tahap perencanaan, penelitian dan pelaporan.

\section{Subjek Penelitian}

Pada penelitian pengembangan ini dilakukan 3 tahap uji coba, yaitu uji coba perorangan (one to one trying out), uji coba kelompok kecil (small group tryout) dan uji coba lapangan (field tryout). Subjek penelitian dalam penelitian pengembangan ini meliputi 3 peserta didik pada uji coba perorangan, 10 peserta didik pada uji coba kelompok kecil, 48 peserta didik pada uji coba lapangan, satu dosen ahli materi, satu dosen ahli media dan satu praktisi pembelajaran Akuntansi Keuangan SMK. Objek uji coba yang diteliti adalah kelayakan media pembelajaran Permainan Edukasi ACAK.

\section{Prosedur}

Berikut adalah langkah-langkah pengembangan:

\section{a. Analisis (Analysis)}

Pengembangan media pembelajaran berbentuk Permainan Edukasi ACAK dimulai dari tahap analisis terhadap kurikulum yang digunakan di SMK YPE Sawunggalih Kutoarjo. Selain melakukan analisis terhadap kurikulum, peneliti juga melakukan analisis terhadap kebutuhan peserta didik dan analisis mata pelajaran.

\section{b. Perancangan (Design)}

Dalam tahap ini dilakukan penyusunan instrumen penilaian kelayakan media pembelajaran untuk peserta didik, ahli materi, ahli media dan praktisi pembelajaran Akuntansi Keuangan SMK. Perancancangan produk media pembelajaran Permainan Edukasi ACAK (storyboard), penyusunan 
materi dan pengumpulan backsound, background, gambar dan tombol untuk pengembangan media pembelajaran Permainan Edukasi ACAK.

\section{c. Pengembangan (Development)}

Terdapat tiga langkah dalam tahapan pengembangan media pembelajaran Permainan Edukasi ACAK yakni pembuatan produk media, validasi ahli materi, ahli media dan praktisi pembelajaran Akuntansi Keuangan SMK, dan revisi.

\section{d. Implementasi (Implementation)}

Tahap implementasi merupakan tahap produk media pembelajaran Permainan Edukasi ACAK diujicobakan kepada peserta didik. Terdapat tiga tahapan dalam pengujicobaan produk media pembelajaran yakni uji coba perorangan, uji coba kelompok kecil dan uji coba lapangan. Dilakukan revisi setelah seluruh tahapan uji coba jika diperlukan.

\section{e. Evaluasi (Evaluation)}

Tahapan terakhir dari prosedur pengembangan ADDIE adalah evaluasi. Pada tahap evaluasi yaitu memperbandingkan hasil yang didapatkan pada setiap tahapan penilaian kelayakan produk media pembelajaran Permainan Edukasi ACAK.

Data, Teknik Pengumpulan Data dan Instrumen

Jenis Data

Data yang dikumpulkan dalam penelitian ini mencakup data kualitatif dan kuantitatif.

\section{a. Teknik Pengumpulan Data}

Instrumen yang digunakan untuk mengumpulkan data adalah kuesioner. Kuesioner atau angket menurut Sugiyono (2011: 142) adalah teknik pengumpulan data yang dilakukan dengan cara memberi seperangkat pertanyaan atau pernyataan tertulis kepada responden untuk dijawabnya.

\section{b. Instrumen}

Instrumen kuesioner pada penelitian pengembangan ini digunakan untuk memperoleh data dari peserta didik kelas XI Akuntansi SMK YPE Sawunggalih, ahli materi, ahli media dan praktisi pembelajaran Akuntansi Keuangan SMK sebagai bahan mengevaluasi media pembelajaran yang dikembangkan. Insrumen penilaian media pembelajaran Permainan Edukasi ACAK menggunakan skala 5 alternatif jawaban: sangat baik, baik, cukup baik, kurang baik dan sangat kurang baik.

\section{Teknik Analisis Data}

Dari data dan informasi yang diperoleh, maka analisis data yang perlu dilakukan adalah analisis data deskriptif kualitatif dan analisis data kuantitatif. Analisis data kualitatif digunakan untuk mengolah data hasil validasi peserta didik, ahli materi, ahli media dan praktisi pembelajaran Akuntansi Keuangan SMK sedangkan analisis data kuantitatif digunakan untuk mengetahui kelayakan media pembelajaran Permainan Edukasi ACAK.

Untuk menganalisis data tentang kelayakan media pembelajaran Permainan Edukasi ACAK dilakukan langkah-langkah sebagai berikut:

a. Mengubah penilaian kualitatif menjadi kuantitatif dengan ketentuan:

\section{Tabel 1. Ketentuan Pemberian Skor}

\begin{tabular}{|l|c|}
\hline \multicolumn{1}{|c|}{ Klasifikasi } & Skor \\
\hline Sangat Baik & $4.1-5.0$ \\
\hline Baik & $3.1-4.0$ \\
\hline Cukup & $2.1-3.0$ \\
\hline Kurang & $1.1-2.0$ \\
\hline Sangat Kurang & 1.0 \\
\hline
\end{tabular}

Sumber: Sugiyono (2011: 93) dengan modifikasi

b. Menghitung nilai rerata skor tiap indikator dengan rumus:

$X=\frac{\Sigma X}{N}$ 
Keterangan:

$\bar{X}=$ skor rata-rata,

$\Sigma X=$ jumlah skor,

$\mathrm{N}=$ jumlah subjek uji coba

c. Menjumlahkan rerata skor tiap aspek

d. Menginterpretasikan secara kualitatif jumlah rerata skor tiap aspek dengan menggunakan rumus konversi skor skala 5 berikut:

Tabel 2. Rumus Konversi Jumlah Rerata Skor

\begin{tabular}{|c|c|c|}
\hline$\frac{\bar{\pi}}{\bar{z}}$ & Skor & لِّ \\
\hline 5 & $\bar{X}>\bar{X} i+1,8 S B i$ & SB \\
\hline 4 & $\begin{array}{c}\bar{X} i+0,6 S B i<\bar{X} \leq \\
\bar{X} i 1,8 S B i\end{array}$ & B \\
\hline 3 & $\begin{array}{c}\bar{X} i-0,6 S B i<\bar{X} \leq \\
\bar{X} i+0,6 S B i\end{array}$ & $\mathrm{CB}$ \\
\hline 2 & $\bar{X} i-1,8$ SB $i<\bar{X}<\bar{X} i-0$, & $S T B B$ \\
\hline 1 & $\bar{X}<\bar{X} i-1,8$ SBi & SKB \\
\hline
\end{tabular}

Keterangan:

$\mathrm{SB}=$ Sangat Baik

$\mathrm{B} \quad=$ Baik

$\mathrm{CB} \quad=$ Cukup Baik

$\mathrm{KB} \quad=$ Kurang Baik

SKB = Sangat Kurang Baik

Skor Maksimal $=5$

Skor Minimal $=1$

Skor Maksimal Ideal = jumlah indikator $\mathrm{x}$ skor tertinggi

Skor Minimal Ideal = jumlah indikator $\mathrm{x}$ skor rendah

$\bar{X} \quad=\begin{array}{lll}\text { skor } & \text { yang } \\ \text { diperoleh } & \end{array}$

$\bar{X} i=\frac{1}{2}$ (skor maks ideal+skor min ideal)

$S B i$ (simpangan baku ideal $)=\frac{1}{6}($ skor maks ideal-skor min ideal)

Sumber: Eko Putro Widyoko (2011: 245)

e. Data yang terkumpul dianalisis deskriptif kuantitatif yang disajikan dalam distribusi skor dan persentase terhadap kategori dengan skala penilaian yang telah ditentukan:

Persentase Kelayakan Tiap Aspek $(\%)=\frac{\text { Ererata skor yang diperoleh }}{\text { Ererata skor ideal }} \times 100 \%$

Tabel 3. Penilaian Kelayakan

\begin{tabular}{|c|c|}
\hline $\begin{array}{c}\text { Persentase } \\
\text { Penilaian }\end{array}$ & Interpretasi \\
\hline $81 \%-100 \%$ & Sangat Layak \\
\hline $61 \%-80 \%$ & Layak \\
\hline $41 \%-60 \%$ & Cukup Layak \\
\hline $21 \%-40 \%$ & Kurang Layak \\
\hline $0 \%-20 \%$ & Tidak Layak \\
\hline
\end{tabular}

Sumber: Suharsimi Arikunto (2010:44)

\section{HASIL \\ PENELITIAN \\ DAN \\ PEMBAHASAN}

\section{Langkah-Langkah Pengembangan \\ Media}

a. Analisis (Analysis)

Pengembangan media pembelajaran Permainan Edukasi ACAK dimulai dari tahap analisis terhadap kurikulum yang digunakan di SMK YPE Sawunggalih. Observasi awal dilakukan ketika peneliti melaksanakan masa KKN PPL (Kuliah Kerja Nyata dan Praktik Pengalaman Lapangan) di Juli 2014 - September 2014 dan observasi lanjutan dilakukan pada 25 Januari 2015. Setelah adanya pengehentian Kurikulum 2013 ternyata SMK YPE Sawunggalih masih tetap menggunakannya hingga tahun ajaran 2014/2015 berakhir. Selain melakukan analisis terhadap kurikulum, peneliti juga melakukan analisis terhadap kebutuhan peserta didik dan analisis mata pelajaran.

\section{b. Perancangan (Design)}

Tahap ini dilakukan perancangan instrumen yang digunakan untuk penilaian kelayakan Permainan Edukasi ACAK berupa kuesioner atau angket kelayakan. Penilaian kelayakan Permainan Edukasi ACAK dilakukan oleh peserta didik di tiga tahapan uji coba, ahli materi, ahli media, dan praktisi pembelajaran Akuntansi Keuangan 
SMK. Aspek kelayakan untuk ahli materi, ahli media dan praktisi pembelajaran Akuntansi Keuangan SMK terdiri dari aspek relevansi materi, evaluasi/latihan soal, bahasa, rekayasa perangkat lunak, komunikasi visual, dan efek untuk strategi pembelajaran sedangkan aspek kelayakan untuk peserta didik terdiri dari aspek motivasi belajar, kemudahan pemakaian, kemenarikan tampilan dan kebermanfaatan. Tahap perancangan ini juga meliputi perancangan Permainan Edukasi ACAK mulai dari flowchart permainan, tampilan permainan yang terdiri sari halaman awal, halaman pengantar, menu utama, level di permainan samapai akhir permainan. Peneliti mengadaptasi permainan Word Search dari penyedia permainan di Android Ice Mochi. Selanjutnya, peneliti menyusun materi, soal dan jawaban yang dimuat di Permainan Edukasi ACAK dan pengumpulan backsound, background, gambar dan tombol untuk Permainan Edukasi ACAK.

\section{c. Pengembangan (Development)}

Tahap pengembangan dalam penelitian ini adalah pembuatan aplikasi media pembelajaran Permainan Edukasi ACAK dilakukan pada bulan Maret 2015 sampai April 2015. Berikut adalah tampilan dari Permainan Edukasi Akuntansi Cari Kata (ACAK):
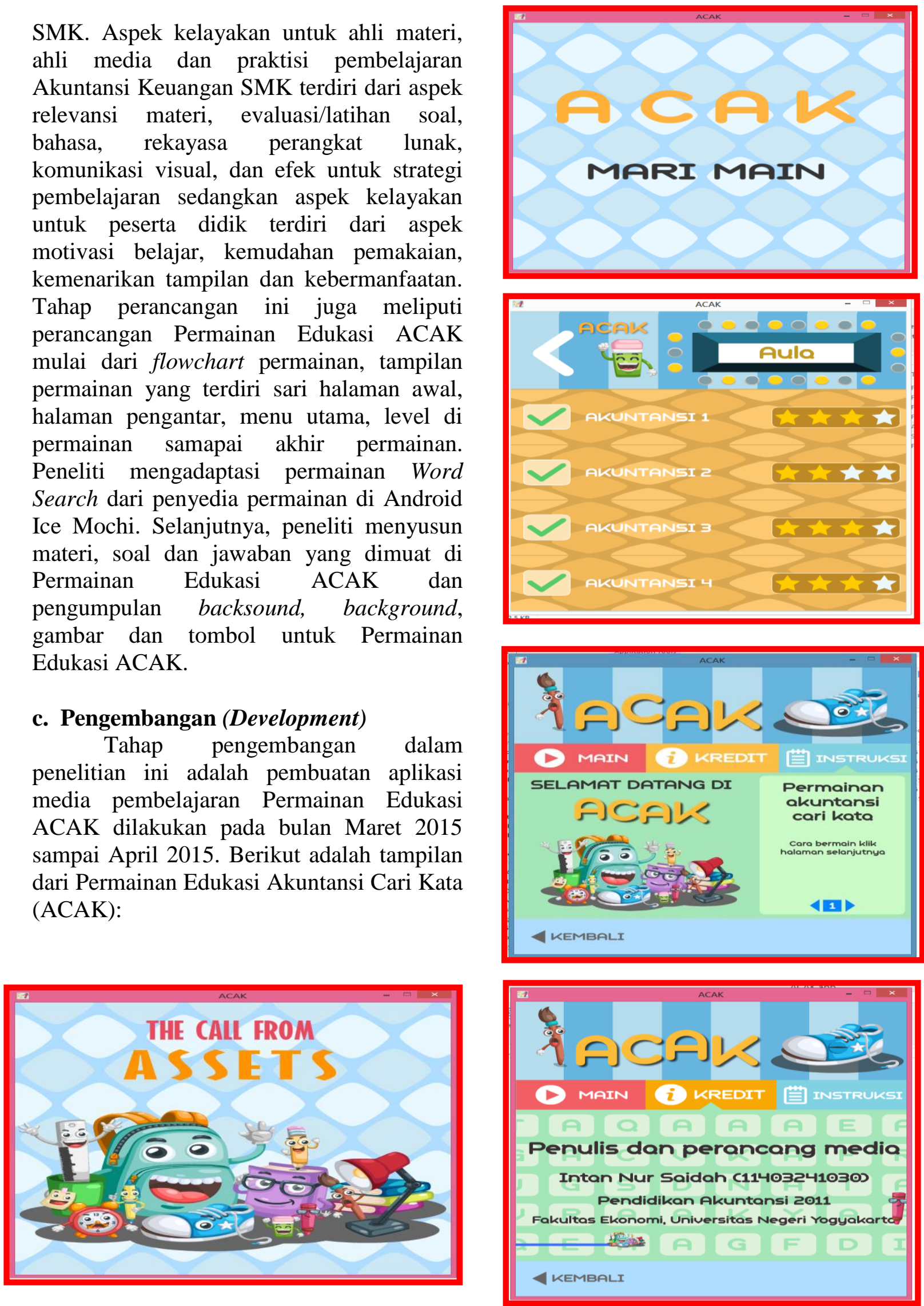
Jurnal Pendidikan Akuntansi Indonesia, Vol. XIII, No.1, Tahun 2015

Intan Nur Saidah \& Mahendra Adhi Nugroho

$65-74$
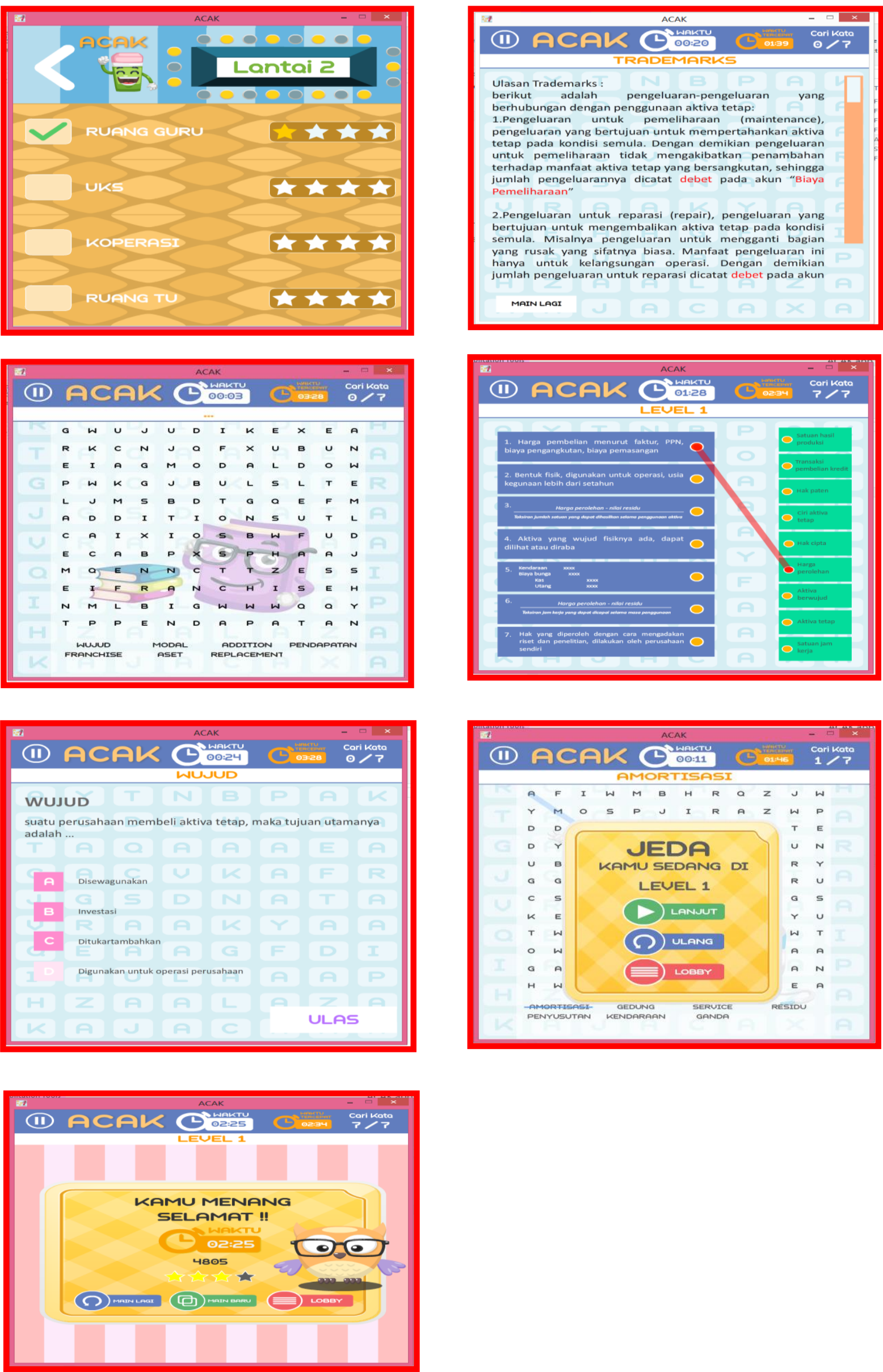


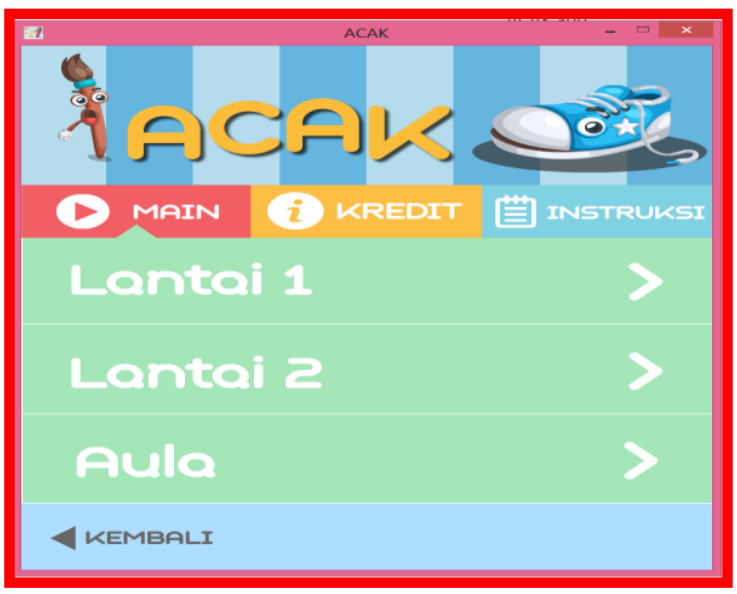

Gambar 1. Hasil Pengembangan Produk

Untuk mengetahui kelayakan media, tahap selanjutnya adalah validasi oleh para ahli. Para validator yaitu satu dosen ahli materi, satu dosen ahli media dan satu praktisi pembelajaran Akuntansi Keuangan SMK. Penilaian kelayakan media pembelajaran dari ahli materi adalah 108 untuk 23 indikator penilaian, memperoleh rerata skor 4.69 (Sangat Baik) dan persentase $93.91 \%$ (Sangat Layak). Penilaian kelayakan media pembelajaran dari ahli media adalah 73 untuk 16 indikator, memperoleh rerata skor 4.56 (Sangat Baik) dan persentase skor 91.25\% ( Sangat Layak). Penilaian kelayakan media pembelajaran dari praktisi pembelajaran Akuntansi Keuangan SMK adalah 116 untuk 27 indikator, memperoleh rerata skor 4.29 (Sangat Baik) dan persentase skor $85.92 \%$ (Sangat Layak). Secara keseluruhan media pembelajaran memperoleh penilaian 297 untuk 66 indikator, memperoleh rerata skor 4.51 (Sangat Baik) dan persentase skor 90\% (Sangat Layak).

\section{d. Implementasi (Implementation)}

Media pembelajaran Permainan Edukasi ACAK diimplementasikan kepada subjek uji coba perorangan, uji coba kelompok kecil dan uji coba lapangan di kelas XI Akuntansi SMK YPE Sawunggalih. Untuk uji coba perorangan, jumlah subjek penelitian adalah 3 peserta didik, uji coba kelompok kecil dengan 10 peserta didik dan uji coba lapangan 48 peserta didik dengan kemampuan akademik yang berbeda. Masing-masing uji coba telah dianalisis dan dihitung tingkat kelayakannya.

Tabel 4. Perbandingan Kelayakan Tahapan Uji Coba

\begin{tabular}{|l|l|l|l|l|}
\hline \multirow{2}{*}{ No } & \multirow{2}{*}{ Aspek } & $\begin{array}{c}\text { Peror } \\
\text { angan }\end{array}$ & $\begin{array}{c}\text { Kel. } \\
\text { Kecil }\end{array}$ & $\begin{array}{c}\text { Lapa } \\
\text { ngan }\end{array}$ \\
\hline 1 & $\begin{array}{l}\text { Motivasi } \\
\text { Belajar }\end{array}$ & 3.80 & 4.24 & 3.13 \\
\hline 2 & $\begin{array}{l}\text { Kemudahan } \\
\text { Pemakaian }\end{array}$ & 4.00 & 3.90 & 3.87 \\
\hline 3 & $\begin{array}{l}\text { Kemenarikan } \\
\text { Tampilan }\end{array}$ & 3.94 & 4.03 & 3.92 \\
\hline 4 & $\begin{array}{l}\text { Keberman- } \\
\text { faatan }\end{array}$ & 4.20 & 4.14 & 3.93 \\
\hline & Jumlah & 15.94 & 16.31 & 14.85 \\
\hline
\end{tabular}

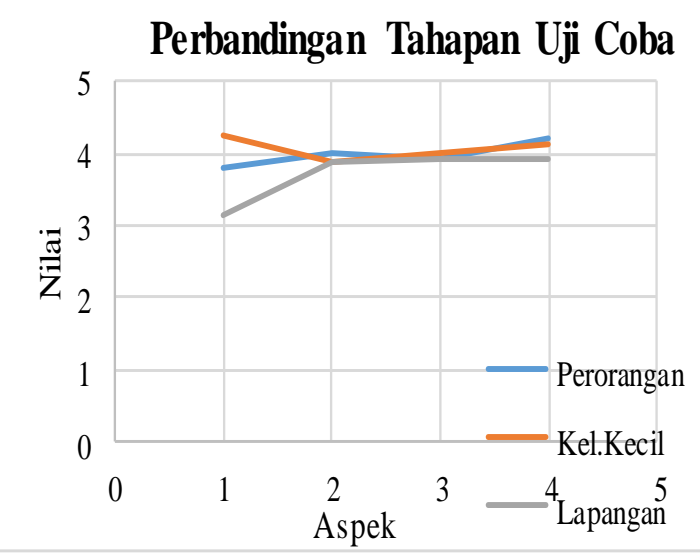

\section{Gambar 2. Perbandingan Tahapan Uji Coba}

\section{e. Evaluasi (Evaluation)}

Kelayakan media diperoleh berdasarkan penilaian ahli materi, ahli media, praktisi pembelajaran Akuntansi SMK dan peserta didik di tahapan uji coba. Penilaian kelayakan media berdasarkan ahli materi meliputi aspek relevansi materi, aspek evaluasi/latihan soal dan aspek efek untuk strategi pembelajaran. Aspek yang dinilai dari ahli media antara lain aspek bahasa, aspek rekayasa perangkat lunak dan aspek komunikasi visual. Praktisi pembelajaran akuntansi SMK juga memberikan penilaian untuk Permainan 
ACAK dari aspek relevansi materi, aspek evaluasi/latihan soal, aspek efek untuk strategi pembelajaran dan aspek bahasa. Uji coba pada peserta didik menilai aspek motivasi belajar, aspek kemudahan pemakaian, aspek kemenarikan tampilan dan aspek kebermanfaatan. Kelayakan media tersebut dari setiap tahapan dapat dilihat pada tabel 5 .

Tabel 5. Kelayakan Setiap Tahapan

\begin{tabular}{|l|l|l|l|l|l|}
\hline Penilaian & $\begin{array}{c}\text { Jum } \\
\text { lah } \\
\text { Sko } \\
\text { r }\end{array}$ & $\begin{array}{c}\text { Rer } \\
\text { ata } \\
\text { Sko } \\
\text { r }\end{array}$ & $\begin{array}{c}\text { Ka } \\
\text { teg } \\
\text { ori }\end{array}$ & $\begin{array}{l}\text { Perse } \\
\text { ntase }\end{array}$ & $\begin{array}{c}\text { Ka } \\
\text { teg } \\
\text { ori }\end{array}$ \\
\hline $\begin{array}{l}\text { Ahli } \\
\text { Materi }\end{array}$ & 108 & 4.69 & SB & $\begin{array}{l}93.91 \\
\%\end{array}$ & SL \\
\hline $\begin{array}{l}\text { Ahli } \\
\text { Media }\end{array}$ & 73 & 4.56 & SB & $\begin{array}{l}91.25 \\
\%\end{array}$ & SL \\
\hline $\begin{array}{l}\text { Praktisi } \\
\text { Pembelaja } \\
\text { ran SMK }\end{array}$ & 116 & 4.29 & SB & $\begin{array}{l}85.92 \\
\%\end{array}$ & SL \\
\hline $\begin{array}{l}\text { Peroranga } \\
\text { n }\end{array}$ & 87.6 & 3.98 & B & $\begin{array}{l}83.49 \\
\%\end{array}$ & SL \\
\hline $\begin{array}{l}\text { Kel.Kecil } \\
8\end{array}$ & $\begin{array}{l}89.5 \\
0\end{array}$ & 4.06 & B & $\begin{array}{l}87.74 \\
\%\end{array}$ & SL \\
\hline Lapangan & 85.2 & 3.87 & B & $\begin{array}{l}81.14 \\
\%\end{array}$ & SL \\
\hline \multicolumn{2}{|c|}{ Rerata } & 4.21 & SB & $\begin{array}{l}86.73 \\
\%\end{array}$ & SL \\
\hline
\end{tabular}

Keterangan: $\mathrm{SB}=$ Sangat Baik, $\mathrm{B}=$ Baik dan SL = Sangat Layak

\section{SIMPULAN DAN SARAN Simpulan}

Berdasarkan hasil penelitian dan pembahasan pada Bab IV, maka penelitian dan pengembangan ini dapat disimpullkan bahwa:

Pengembangan media pembelajaran Permainan Edukasi ACAK melalui lima tahap yaitu analisis (analysis), perancangan (design), pengembangan (development), implementasi (implementation) dan evaluasi (evaluation).

Tingkat kelayakan Permainan ACAK diketahui berdasarkan penilaian kelayakan dari satu dosen ahli materi, satu dosen ahli media, satu praktisi pembelajaran Akuntansi
Keuangan SMK dan peserta didik di setiap tahapan uji coba.

Penilaian kelayakan oleh ahli materi diperoleh rerata skor 4.69 (Sangat Baik) dan 93.91\% (Sangat Layak). Penilaian kelayakan oleh ahli media diperoleh rerata skor 4.56 (Sangat Baik) dan 91.25\% (Sangat Layak). Penilaian kelayakan oleh praktisi pembelajaran Akuntansi Keuangan SMK diperoleh rerata skor 4.29 (Sangat Baik) dan 85.92\% (Sangat Layak). Respon peserta didik kelas XI Akuntansi dengan adanya media pembelajaran Permainan Edukasi ACAK pada aspek motivasi belajar, kemudahan pemakaian, kemenarikan tampilan dan kebermanfaatan. Pada uji coba perorangan diperoleh rerata skor 3.98 (Baik) dan $83.49 \%$ (Sangat Layak). Pada uji coba kelompok kecil diperoleh rerata skor 4.06 (Baik) dan 87.74\% (Sangat Layak). Pada uji coba lapangan diperoleh rerata skor 3.87 (Baik) dan 81.14\% (Sangat Layak).

\section{Saran}

Berdasarkan penelitian pengembangan dan batasan pengembangan seperti telah dijelaskan, Permainan Edukasi ACAK sebagai media pembelajaran masih memiliki banyak kelemahan. Oleh karena itu, beberapa saran pemanfaatan dan pengembangan produk lebih lanjut yang dibutuhkan adalah sebagai berikut:

Waktu pengembangan Permainan Edukasi ACAK diperpanjang, mulai dari tahap analisis sampai evaluasi produk sehingga penelitian pengembangan dilakukan secara maksimal. Penelitian selanjutnya sebaiknya selain mengukur kelayakan media juga menghitung tingkat efektivitasnya. Instrumen penelitian dalam Permainan Edukasi ACAK seharusnya divalidasi oleh ahli terlebih dahulu sehingga dapat diketahui kualitasnya. 
DAFTAR PUSTAKA

Azhar Arsyad. (2011), Media Pembelajaran. Jakarta: Raja Grasindo Persada.

Branch, Robert Maribe. (2009). Instructional Design: The ADDIE Approach. Athena: Springer.

Eko Putro Widyoko. (2011). Evaluasi Program Pembelajaran. Yogyakarta: Pustaka Belajar.

Galih Pranowo. (2011). Kreasi Animasi Interaktif dengan Action Script 3.0 pada Flash CS5. Yogyakarta: Penerbit Andi.

Hamzah B. Uno. 92006). Model Pembelajaran Menciptakan Proses
Belajar Mengajar yang Kreatif dan Efektif. Jakarta: Bumi Aksara.

Sugiyono. (2011). Metode Penelitian Kuantitatif, Kualitatif dan $R \& D$. Bandung: Alfabeta.

Sugar, Steve dan Kim Kostoroski Sugar. (2002). Primary Games: Experimental Learning Activities for Teaching Children K-8. San Fransisco: Jossey Bass

Suharsimi Arikunto. (2010). Prosedur Penelitian Pendekatan Praktik. Jakarta: $\quad$ Rineka Cipta 